\title{
Host records for Phytophthora multivora associated with dieback in Victoria, Australia
}

\author{
R. Aldaoud ${ }^{1}$ (I) $\cdot$ S. Salib ${ }^{1} \cdot$ S. Q. Dinh ${ }^{1} \cdot$ S. de Alwis ${ }^{1} \cdot$ R. J. Holmes $^{1} \cdot$ J. Edwards $^{1}$
}

Received: 15 September 2015 / Accepted: 11 February 2016 / Published online: 24 February 2016

(C) Australasian Plant Pathology Society Inc. 2016

\begin{abstract}
Phytophthora multivora was detected from several soil samples collected from the rhizospheres of diebackaffected plants between 2009 and 2014 in the Melbourne Gardens, Royal Botanic Gardens Victoria and the Melbourne Museum, both located in inner city Melbourne, Victoria.
\end{abstract}

Keywords Agapanthus - Eucalyptus · Grevillea · Howea · Sassafras $\cdot$ Xanthorrhoea

Between February 2009 and June 2014, samples of rhizosphere soil from several dieback-affected plants in the Melbourne Gardens, Royal Botanic Gardens Victoria (RBG), Australia, were submitted to the Victorian government's plant diagnostic laboratory, Crop Health Services (CHS), to investigate the cause of the dieback. During this period, another sample was submitted by Victoria's Biosecurity surveillance team to investigate the cause of a dying Sassafras sp. in the Living Rainforest exhibit of the Melbourne Museum. There was a diverse range of 11 hosts represented (Table 1). Typical symptoms included wilting, necrosis, rotted roots and internal wood discolouration and necrosis (e.g. Howea forsteriana, Fig. 1).

Using the laboratory's routine pear baiting method based on Tsao (1983), soft rot lesions developed within 1-3 weeks in the pears used to bait soil from the rhizosphere of the diseased plants. The lesion surfaces were sterilised with $80 \%$ ethanol,

R. Aldaoud

ramez.aldaoud@ecodev.vic.gov.au

1 Crop Health Services, Agriculture Victoria, Department of Economic Development, Jobs, Transport and Resources, AgriBio Centre for Biosciences, LaTrobe University, 5 Ring Road,

Bundoora, VIC 3083, Australia internal pear tissue was excised from the diseased-healthy interface of the soft rot and plated onto $1.5 \%$ water agar (Oxoid, Agar Technical, Agar No. 3) and $4 \%$ V8 juice agar (Original Campbell's Soups Australia, pH adjusted to 6.5 prior to adding $1.5 \%$ agar) media. The plates were incubated at $24{ }^{\circ} \mathrm{C}$ with a $12 \mathrm{~h} \mathrm{light/dark}$ cycle, inspected daily and any subsequent growth was subcultured by excising hyphal tips onto fresh Potato Dextrose Agar (PDA) or V8 media plates.

A Phytophthora-like pathogen was routinely isolated from the rot-affected baiting pear tissues. To confirm the genus, $1 \mathrm{~cm}^{2}$ agar blocks were cut from the colonies growing on V8 juice media and floated in sterile Petri dishes containing non-sterile soil-water extract. Within 5 days, typical Phytophthora-shaped sporangia had formed and zoospore discharge was observed. The sporangia were semipapillate and either limoniform, ellipsoid or obpyriform (Fig. 2a), the oogonia were globose and borne terminally, and the antheridia were irregular and paragynous (Fig. 2b). Morphology and size were consistent with the range reported for P. multivora (Scott et al. 2009). Koch's postulates were not undertaken due to the diversity and maturity of the hosts. The consistent association with symptoms known to be attributable to $P$. multivora, plus the lack of detection of other potential causal agents, was considered to be sufficient evidence of causality.

To confirm the identification, clean mycelia obtained from hyphal tip culturing were used for genomic DNA extraction. Mycelia were collected from cultures grown on potato dextrose agar, and macerated in a tissue lyser (QIAGEN). Genomic DNA was extracted using DNeasy Plant Mini Kits (QIAGEN) according to the manufacturers' instructions. The regions spanning the ribosomal DNA internal transcribed spacer region (ITS) and mitochondrial cytochrome c oxidase subunit 1 ( $\operatorname{cox} 1)$ gene were amplified using primers ITS5 and 
Table 1 Isolates of Phytophthora multivora obtained from rhizosphere soil of plants showing dieback in Melbourne

\begin{tabular}{|c|c|c|c|c|c|c|}
\hline \multirow[t]{2}{*}{ Isolate } & \multirow[t]{2}{*}{ Date } & \multirow[t]{2}{*}{ Origin $^{\mathrm{a}}$} & \multirow[t]{2}{*}{ Associated plant } & \multirow{2}{*}{$\begin{array}{l}\text { Common names } \\
\text { of plants }\end{array}$} & \multicolumn{2}{|c|}{ GenBank accession no. } \\
\hline & & & & & ITS & $\operatorname{cox} 1$ \\
\hline VPRI 41501 & Feb 2009 & RBG & Drimys winteri & Winter's bark & KU593618 & - \\
\hline CHS 1 & May 2009 & RBG & Podocarpus sp. & Podocarp & KU146526 & - \\
\hline CHS 2 & May 2009 & RBG & Quercus robur & Oak & KU530160 & - \\
\hline CHS 3 & Dec 2009 & RBG & Cinnamomum camphora & Camphor laurel & KU593611 & - \\
\hline CHS 4 & July 2010 & RBG & Agapanthus praecox & Agapanthus & KU593612 & - \\
\hline CHS 5 & Dec 2010 & $\mathrm{MM}$ & Sassafras sp. & Sassafras & KU593613 & - \\
\hline CHS 6 & Feb 2012 & RBG & Eucalyptus victrix & $\begin{array}{l}\text { Smooth-barked } \\
\text { coolibah }\end{array}$ & KU593614 & - \\
\hline CHS 7 & March 2014 & RBG & Podocarpus nivalis & Alpine totara & KU593615 & KU593620 \\
\hline CHS 8 & March 2014 & RBG & Xanthorrhoea australis & Grass-tree & KU593616 & - \\
\hline CHS 9 & March 2014 & RBG & Grevillea shiressii & - & KU593617 & KU593621 \\
\hline VPRI 42425 & June 2014 & RBG & Howea forsteriana & Kentia palm & KU593619 & KU593622 \\
\hline
\end{tabular}

${ }^{a} R B G$ Royal Botanic Gardens Melbourne, $M M$ Melbourne Museum

ITS4 (White et al. 1990) and FM84 and FM83 (Martin and Tooley 2003), respectively. The PCR products were purified using QIAquick PCR Purification Kits (QIAGEN), and sequenced using the full cycle Sanger DNA sequencing service offered by Micromon, Monash University, Melbourne (https://platforms.monash.edu/micromon/). ITS sequences were generated for all eleven isolates, but cox 1 sequences were only generated for three isolates (CHS 7, CHS 9, VPRI 42425). The sequence data were edited using Geneious software version 7 created by Biomatters (www.geneious.com). The sequences were then subjected to BLAST searches on GenBank (http://www.ncbi.nlm.nih.gov) and the Phytophthora Database (http://phytophthora-id.org/) to find the closest sequence matches, and aligned in Geneious to confirm identity. They were all 99.9-100\% similar to the ex-type sequence of $P$. multivora. Using Geneious, neighbour-joining

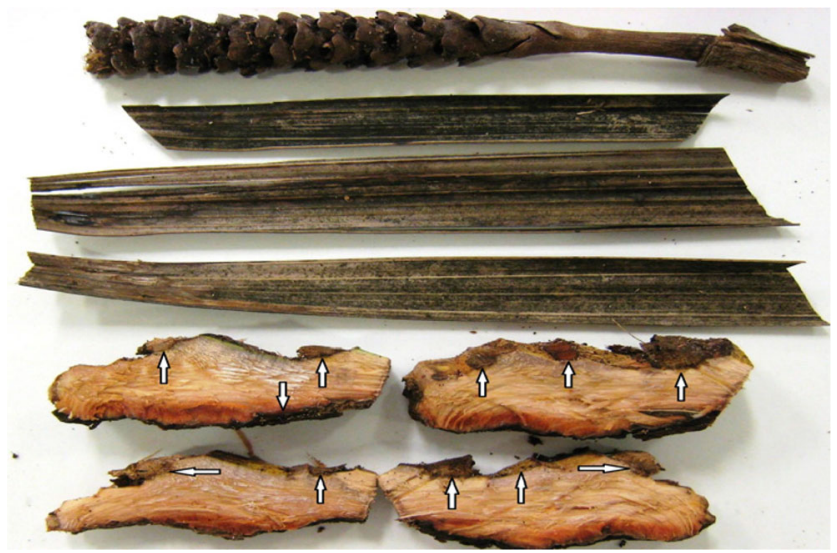

Fig. 1 Howea forsteriana: Disease symptoms on flowering parts and leaves and stem bases of plant growing on soil infested with Phytophthora multivora. Note internal pocket rots indicated by white arrows inference phylogenetic trees were built to show phylogenetic relationships between our isolates and representative isolates from the P. multivora - P. citricola complex (Figs. 3 and 4). Most isolates were lost after the work was finished but two cultures were still viable and deposited in the Victorian Plant Pathology Herbarium (VPRI) as accessions VPRI 41501 and VPRI 42425, respectively.

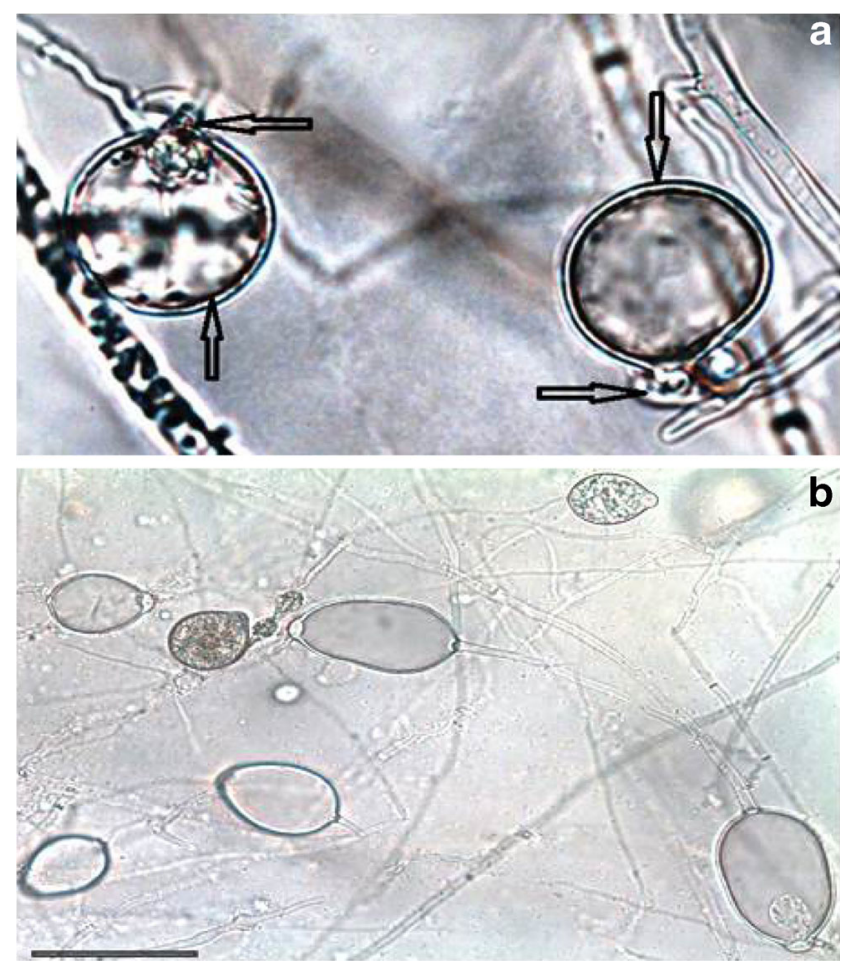

Fig. 2 Phytophthora multivora ex. Howea forsteriana: a antheridia and oogonia; b sporangia; scale bar $=25 \mu \mathrm{m}$ 


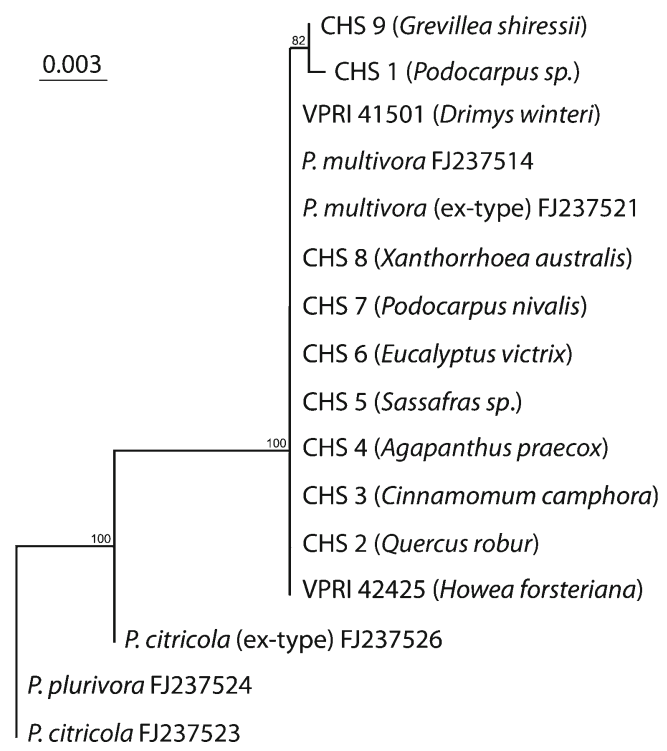

Fig. 3 Neighbour-joining inference phylogenetic tree (built using Geneious 7) comparing ITS gene sequence data of the Crop Health Service isolates with reference sequences from GenBank including the ex-type specimens of Phytophthora multivora and Phytophthora citricola. The respective associated plants are provided in parentheses

Phytophthora species are well known for causing rots, dieback, defoliation and death in numerous host plants worldwide. Phytophthora multivora was first described from declining Eucalyptus, Banksia, Agonis and other plant species in Western Australia, recovered during extensive testing for $P$. cinnamomi (Scott et al. 2009). In Australia, disease in natural ecosystems (Jarrah dieback, Phytophthora dieback, dieback) has been attributed to P. cinnamomi, and is considered a key threatening process to Australia's natural environment under the Environment Protection and Biodiversity Conservation Act 1999 (EPBC Act 1999). In pathogenicity trials, infesting the rhizospheres of young trees with P. multivora isolates significantly reduced the fine root surface area and the number of root tips on Eucalyptus gomphocephala and E. marginata, and

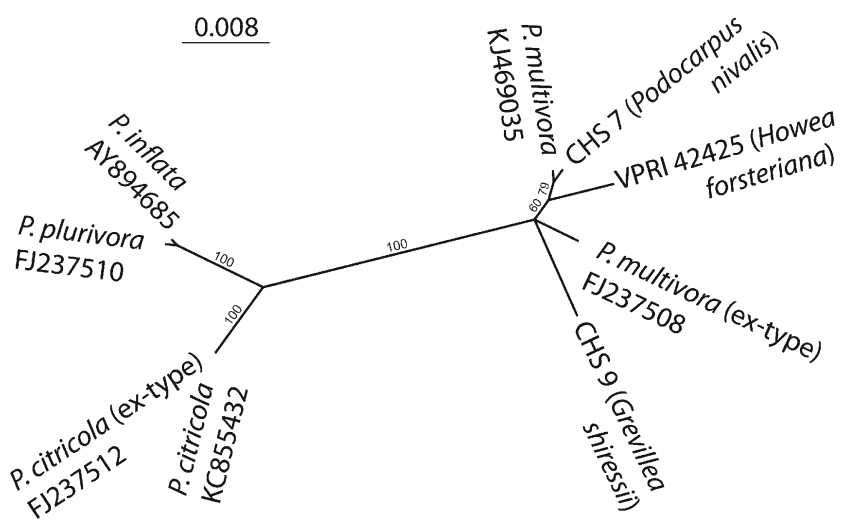

Fig. 4 Neighbour-joining inference phylogenetic tree (built using Geneious 7) comparing cox 1 gene sequence data of the Crop Health Service isolates with reference sequences from GenBank including the ex-type specimens of Phytophthora multivora and Phytophthora citricola. The respective associated plants are provided in parentheses under-bark inoculation caused significantly expanded rot lesions (Scott et al. 2012). According to Callaghan and Guest (2015), P. multivora is now considered the second-most widespread Phytophthora species in Western Australia after $P$. cinnamomi, and at many sites it is $P$. multivora rather than $P$. cinnamomi that causes tree mortality. Since first described, it has been reported from declining Wollemia nobilis (Wollemi pine) in New South Wales (Puno et al. 2015), lucerne (Bezuidenhout et al. 2010) and citrus (Meitz-Hopkins et al. 2014) in South Africa, soybean in Japan (Rahman et al. 2014, 2015), oaks in Hungary (Szabó et al. 2013), Viburnum spp. in Switzerland (Prospero et al. 2013), and from soil in the UK (Henricot et al. 2014).

Morphologically $P$. multivora resembles $P$. citricola, and many earlier collections of $P$. citricola in WA were later determined to belong to P. multivora (Scott et al. 2009). In the Victorian Plant Pathology Herbarium, there are several collections of P. citricola prior to 2009, but without molecular comparison it is not possible to know if these are in fact $P$. multivora. Therefore, to our knowledge, these are the first records of $P$. multivora from Victoria. All are on new hosts, and all are from two sites within inner metropolitan Melbourne. In some cases, the incidence of disease reported by the client (RBG) was severe. For example, $30 \%$ of $>20$ year old Podocarp trees in the garden bed of the RBG were affected (CHS 1), $75 \%$ of the $>20$ year old oaks (CHS 2) in the oak lawn were affected by sporadic dieback, $100 \%$ of the Agapanthus plants (CHS 4) and smooth-barked coolibah trees (CHS 6) in their respective beds were affected. In Western Australia, this pathogen has now been linked with decline and death of urban trees in Perth (Barber et al. 2013).

Although all of the new hosts reported here were growing as ornamental plants in the city, Grevillea shiressii and $H$. forsteriana are considered vulnerable in their natural habitats (Gosford, NSW; Lord Howe and Norfolk Islands, respectively). P. multivora has been recently found causing disease within the Gondwana Rainforests of Australia World Heritage Area (Scarlett et al. 2015) and the Wollemi National Park, NSW (Puno et al. 2015), both eastern coastal areas of Australia. These new host reports provide support to concerns raised about the impact that $P$. multivora could have if spread through the Australian natural environment (Callaghan and Guest 2015; Scarlett et al. 2015).

\section{References}

Barber PA, Paap T, Burgess TI, Dunstan W, Hardy GESJ (2013) A diverse range of Phytophthora species are associated with dying urban trees. Urban For Urban Green 12:569-575

Bezuidenhout CM, Denman S, Kirk SA, Botha WJ, Mostert L, McLeod A (2010) Phytophthora taxa associated with cultivated Agathosma, with emphasis on the $P$. citricola complex and $P$. capensis sp. nov. Persoonia 25:32-49 
Callaghan S, Guest D (2015) Globalisation, the founder effect, hybrid Phytophthora species and rapid evolution: new headaches for biosecurity. Australas Plant Pathol 44:255-262

Henricot B, Perez Sierra A, Jung T (2014) Phytophthora pachypleura sp. nov., a new species causing root rot of Aucuba japonica and other ornamentals in the United Kingdom. Plant Pathol 63: 1095-1110

Martin FN, Tooley PW (2003) Phylogenetic relationships among Phytophthora species inferred from sequence analysis of mitochondrially encoded cytochrome oxidase I and II genes. Mycologia 95:269-284

Meitz-Hopkins J, Pretorius M, Spies C, Huisman L, Botha W, Langenhoven S, McLeod A (2014) Phytophthora species distribution in South African citrus production regions. Eur J Plant Pathol 138:733-749

Prospero S, Vercauteren A, Heungens K, Belbahri L, Rigling D (2013) Phytophthora diversity and the population structure of Phytophthora ramorum in Swiss ornamental nurseries. Plant Pathol 62:1063-1072

Puno V, Laurence M, Guest D, Liew E (2015) Detection of Phytophthora multivora in the Wollemi pine site and pathogenicity to Wollemia nobilis. Australas Plant Pathol 44:205-215

Rahman MZ, Uematsu S, Coffey MD, Uzuhashi S, Suga H, Kageyama K (2014) Re-evaluation of Japanese Phytophthora isolates based on molecular phylogenetic analyses. Mycoscience 55:314-327
Rahman MZ, Uematsu S, Suga H, Kageyama K (2015) Diversity of Phytophthora species newly reported from Japanese horticultural production. Mycoscience 56:443-459

Scarlett K, Daniel R, Shuttleworth L, Roy B, Bishop T, Guest D (2015) Phytophthora in the Gondwana rainforests of Australia World Heritage Area. Australas Plant Pathol 44:335-348

Scott PM, Burgess TI, Barber PA, Shearer BL, Stukely MJC, Hardy GEStJ, Jung T (2009) Phytophthora multivora sp. nov., a new species recovered from declining Eucalyptus, Banksia, Agonis and other plant species in Western Australia. Persoonia 22:1-13

Scott PM, Jung T, Shearer BL, Barber PA, Calver M, Hardy GEStJ (2012) Pathogenicity of Phytophthora multivora to Eucalyptus gomphocephala and Eucalyptus marginata. For Pathol 42:289-298

Szabó I, Lakatos F, Sipos G (2013) Occurrence of soilborne Phytophthora species in declining broadleaf forests in Hungary. Eur J Plant Pathol 137:159-168

Tsao PH (1983) Factors affecting isolation and quantitation of Phytophthora from soil. In: Erwin DC, Bartnicki-Garcia S, Tsao PH (eds) Phytophthora: its biology, taxonomy, ecology, and pathology. American Phytopathological Society, St. Paul, pp 219-236

White TJ, Bruns TD, Lee S, Taylor JW (1990) Amplification and direct sequencing of fungal ribosomal RNA genes for phylogenetics. In: Innis MA, Gelfand DH, Sninsky JJ, White TJ (eds) PCR protocols: a guide to methods and applications. Academic Press, Orlando, pp $315-322$ 